\title{
Senior high school mathematics teachers' perception and use of assessment in the classroom
}

\author{
M. Okyere ${ }^{1}$ and E. Larbi ${ }^{2}$
}

\begin{abstract}
The study investigated senior high school mathematics teachers' perception and practices of classroom assessment since assessment is considered a critical tool to assessing the achievement of learning objectives in particular and educational goals in general. The study adopted the mixed methods design. Sixty-two mathematics teachers were sampled from the selected schools to participate in the study. The instrument used in the data collection was a questionnaire. The internal consistency of the instrument designed had a calculated Cronbach alpha reliability coefficient of 0.74 . The quantitative data gathered were analysed using descriptive statistics. The results from the study revealed that mathematics teachers had positive perception about classroom assessment as most of them indicated that assessment is a tool to inform teaching and learning. There were however, few teachers who still had negative perception about assessment. Their reasons being that assessment had always been a tool for assigning grades and also used to promote students, hence had little benefit to teaching and learning process. The study also showed that the mathematics teachers' practices of classroom assessment did not match up to the views they held about classroom assessment. Retraining of teachers through seminars and workshops were therefore recommended.
\end{abstract}

Keywords assessment; teachers' perceptions; teachers' assessment practices; decision making.

\section{Introduction}

One of the critical components of teacher activities in the classroom is assessment since it serves as a basis for almost every decision made about students' learning in the classroom (McMillan, 2008). Teachers take regular decisions about their teaching, particularly what to do, how to go about it and how to ensure that it is done to expectation. Sound decisions need to be taken before, during and after teaching. To a large extent, assessment impacts everything the teacher does in the classroom. Hence, there can be no effective teaching and sound decision making about students' learning without classroom assessment (Okyere, Kuranchie, Larbi \& Twene, 2018).

Obtaining information about students' learning is an indispensable tool for effective teaching. The decision taken by the teacher serves a useful purpose to both the teacher and the learner. Assessment enables the teacher to modify teaching methods to meet students' learning needs (Martinez, Stecher, \& Barko, 2009; Nsikak-Abasi, \& Akanaono, 2017; Okyere et al, 2018). Appropriate feedback offered to students often enable them to demonstrate significant improvement in learning. The main goal of any teaching activity is to ensure the achievement of set objectives. Student competencies can be determined by collecting data about their learning, analysing the data and using the information obtained to determine the degree to which the learning objectives have been achieved. Thus, assessment also enables students' progress in course of instruction to be determined. According to Mussawy (2009), there is significant impact of assessment on students' performance. Assessment therefore is seen as an integral part of teaching. According to Oduro (2015), assessment, when integrated into teaching and learning has the potential of motivating students to learn.

\footnotetext{
${ }^{1 \& 2}$ Mavis Okyere and Ernest Larbi are lecturers at the Catholic University College of Ghana, Fiapre, Sunyani. Email: okyere@ualberta.ca
}

Open Access article distributed under the terms of the Creative Commons Attributions License [CC BY-NC-ND 4.0] http://creativecommons.org/licenses/by-nc-nd/4.0. DOI: https://dx.doi.org/10.4314/ajesms.v15i2.4 
Students' learning outcome can be predicted through constant and regular assessment of how they progress with instruction. Students who are not regularly assessed during instruction are likely to proceed with their learning difficulties through to end of term/semester examinations. Hence, it is important that teachers who control activities in the classroom make use of assessment tools such as oral questioning, paper and pencil testing in teaching, provide immediate feedback to students and help remediate students' learning difficulties. Thus, assessment also provides an avenue for teachers to interact with students. It enables the teacher to understand and evaluate the thought processes underlying students' response to issues (Nsikak-Abasi, \& Akanaono, 2017). According to Koloi-Keaikitse (2012), teachers' ability to develop and use assessment during instruction enables students' learning difficulties to be addressed, enhances understanding, and improves their thought processes.

\section{Statement of the Problem}

The importance of assessment in determining the achievement of students' learning endeavour cannot be underestimated. Based on general goals of learning mathematics, teachers establish instructional objectives to be attained by the end of every interaction. The achievement of these goals is established through assessment practices. Assessment provides both students and teachers with information about progress towards the achievement of objectives set by the teacher and the general goals of learning mathematics. However, some teachers see assessment and teaching and learning to be two isolated components of classroom activities (Azuka, 2014). Such teachers may conduct assessment without considering the importance of assessment in teaching and learning. According to the author, the actual goal of teaching and learning cannot be realized without assessment irrespective of how good teachers may be, the intelligent level of the students or utilization of audio-visual equipment in teaching. The chief examiners' reports, which serve as feedback on students' general performance on national examinations, has over the years highlighted some basic students' learning difficulties in mathematics which were supposed to have been identified and remedied by teachers if indeed assessment has been constantly carried out with the aim of improving students' learning (WAEC Chief Examiner's report, 2008, 2011, 2014).

Students' low achievement in mathematics has in most cases been attributed to such factors as underperformed teachers, poor students' attitude to mathematics (Eshun, 2000; Yara, 2009). Unfortunately, there seems to be very little or no attention given to the perception and practices of teachers on classroom assessment, an important aspect of teaching and learning. Base on the findings of several works on classroom assessment, many authors call for greater need of its integration into teaching and learning (Zhang \& Burry-Stock, 2003; Susuwele-Banda, 2005). The study therefore aims at investigating senior high school mathematics teachers' perception and practices of classroom assessment.

\section{Research Questions}

The following research questions are set to guide the study:

1. What perception do senior high school mathematics teachers hold about classroom assessment?

2. What factors influence such perceptions about assessment?

3. What kind of assessment practices are utilized by senior high school mathematics teachers in teaching?

4. What relationship exists between teachers' perception of classroom assessment and their practices? 


\section{Review of Literature}

Concept and Definition of Classroom Assessment

The concept of assessment is as old as human race. As man began to compare what he had to that of another person's, or how many acres of land needs to be cultivated to feed families of different sizes, data were obtained to enable decisions of some sort to be made. Thus, most decisions in life are often taken based on information gathered around us (Joshua, 2005). Similarly, in the classroom, several decisions are taken regularly based on the information obtained. This information enables one to better understand classroom activities with the aim to improving upon it. This has led to several definitions of assessment by many authors.

The National Council of Teachers of Mathematics (NCTM, 1995) defines assessment as "the process of gathering evidence about a student's knowledge of, ability to use, and disposition towards mathematics and making inferences from that evidence for a variety of purposes" (p.3). It involves determining the quality of student growth, development and achievement in learning. According to Nitko (2001), assessment is a process of collecting information that is used to make decisions about students' learning, curricula, programmes and educational policy. Determining the achievement of learning outcomes calls for obtaining several kinds of data through different means to inform such decision. Assessment is a process of collecting data about students' learning, analyzing and synthesizing the information to improve the quality of their learning (Okyere, et al, 2018). It enables students' competence to be determined. In other words, it enables the degree to which learning objectives have been achieved to be ascertained by the teacher. Through assessment, teachers get to understand their students better, what they had attained and what they need to learn. In formal sense, assessment as a process encompasses testing, measurement and evaluation. However, in assessment, both formal and informal methods of data collection can be employed (Joshua, 2005).

\section{Formative and Summative Assessment}

Basically, there are two types of assessment. These are formative and summative assessment. Formative assessment is the type which takes place during instruction. It is used to monitor students' learning towards the achievement of set targets. It enables students' progress with instruction to be monitored. Its prime focus is to monitor and improve upon students' learning and classroom activities (Nsikak-Abasi, \& Akanaono, 2017; Nortvedt, \& Buchholtz, 2018). Hence, it is often called assessment for learning. It takes place during the interaction between teachers and the learners in the classroom (Okyere et al, 2018; Amua-Sekyi, 2016). Since its prime focus is to improve upon students' learning, it seeks to identify students' learning difficulties or deficiencies and for any remediation where necessary to enhance performance of the students (Ajogbeje, 2013; Nortvedt, \& Buchholtz, 2018). This makes formative assessment diagnostic in nature. It is meant to improve upon teaching, learning and understanding. Some formative assessment procedures are class tests, project work, assignments, presentations, quizzes. (Okyere, et al, 2018). Popham (as cited in Agyei \& Mensah, 2018) asserts that tests enable students' strengths and weaknesses to be diagnosed and remedied for students' development. It also helps in making decisions regarding preparation for further learning.

Providing immediate feedback is an element of formative assessment. It is often said that assessment is important to the extent to which it leads to the improvement of students' learning. The need therefore for prompt and immediate feedback during assessment. Giving prompt feedback to students enables them to identify their strength and weakness in learning and improve upon. According to Laurillard (as cited in Amua-Sekyi, 2016), feedback is not only providing 
scores on performance to students but also engaging them in dialogue, discussing thoroughly with students to better understand the thought processes underlying students' performance. This ongoing form of exercise enables students to learn from their mistakes, be more experimental and develop more desirable higher cognitive skills (Okyere, et al, 2018). Studies show that the kinds of feedback most teachers give to students are their scores on performance. For instance, in a study conducted on classroom assessment practices, Susuwele-Banda (2005) found that the most provided form of feedback in assessment was provision of just scores. He reported a typical response of one respondent in the study as 'giving scores/grades to students would help them to improve (p. 114).

Focusing on feedback in classroom assessment, Azuka (2014) conducted a study on assessment in mathematics classrooms. One hundred and fifty teachers were sampled for the study. Analysis of the data collected using the mathematics assessment construction scale questionnaire revealed that most of the teachers gave prompt feedback to students in terms of scores on performance. However, about $48 \%$ of the participants in the study did not give remediation lessons to rectify students' learning difficulties or weaknesses in learning. According to the author, assessment should not only focus on process and outcome but should extend to improving learning by diagnosing and remediating students' learning difficulties through discussion of assessment results. In an ideal situation, just giving a student feedback on scores of performances does not give any clarity as far as the purpose of classroom assessment is concerned. Based on this finding, the author recommended that mathematics teachers should make it a practice to give remediation lessons after tests to improve upon students' learning.

Formative assessment greatly influences students' achievement. Agyei and Mensah (2018) conducted a study to investigate the impact of weekly class tests together with other methods of formative assessment (class presentation, and projects) on students' learning outcomes in mathematics. The study participants were 145 year-one senior high school students. The analysis of data collected using questionnaire and scores on the weekly tests and end of term examination revealed that scores on the various methods of formative assessment correlated with the end of term exams, with class test being the best predictor.

Summative assessment, on the other hand, is carried out at the end of course or programme. It is used to determine the students' achievement on a course or programme. It is to determine the sum total of what the students have learnt over the entire period of instruction. It is therefore called assessment of learning (Okyere, et al, 2018; Amua-Sekyi, 2016). It aims at determining what has been learnt or achieved, and in most cases, it leads to grading and certification. According to Awoniyi and Fletcher (2014), summative assessment enables judgment to be made about student achievement on current programme of study, potentials for enrolling in subsequent programmes, and certification. Summative assessment also provides information for selection and placement. In short, summative assessment provides evidence of a students' competence on a programme of study.

\section{Perception and practices of classroom assessment}

The effectiveness of classroom assessment in schools has not been realised as expected by many stakeholders of education. The problems affecting this effectiveness have been attributed to such factors as lack of time, storage facilities, knowledge of assessment techniques, large class sizes and workload on teachers (Azuka, 2014). It is believed that ineffectiveness of classroom assessment goes beyond these to include the kind of perception teachers hold on classroom assessment. Teachers' use of assessment in the classroom is believed to be highly influenced by their perception. Teachers who see assessment to be a tool to improving learners' performance are likely to use it quite often in class. Teachers play important role in mathematics system. For the 
general goal of learning mathematics to be reaslised, teachers play a very critical role of primary assessors of students' learning progress. Hence, teachers' knowledge and expertise in assessment and practices are very crucial to the job performance.

Due to the importance of classroom assessment in schools, Nitko (2001) and McMillan (2008) assert that teachers need to demonstrate high capability of basic assessment competencies as they mostly engage in activities that are assessment-related. This value attached to classroom assessment has initiated a lot of research attempting to investigate teachers' perception and practices of assessment. It is believed that studying this aspect of teaching activities will show how assessment is perceived and practiced by teachers and how it can be improved if misused or poorly perceived (Chester \& Quilter as cited in Susuwele-Banda, 2005).

The NCTM (1995) believes that assessment has the potential to enhance students' interest in learning mathematics. Teachers therefore must use assessment in class to encourage active participation and provide students the freedom to explore mathematical ideas. This makes provision for students' understanding of mathematical concepts and learning growth to be monitored (NTCM, 2000). As many researchers seem to investigate into how to improve on learning outcomes, more emphasis seems to be placed on classroom assessment. For instance, the quest to improve education and students' performance in national examinations made SusuweleBanda (2005) focused attention on classroom assessment, as it has been considered as an effective tool for teaching and learning mathematics (NCTM, 2000). His study sought to understand the extent to which teachers made use of different classroom assessment methods to support teaching and learning of mathematics. The study revealed that most teachers perceived classroom assessment as tests given to students on timely bases often used for grading. Few participants considered assessment as a tool for promoting students. As a result of this, limited abilities were demonstrated in using different methods and tools to assess students' learning during teaching. Zhang and Burry-Stock (2003) believed classroom assessment to be a broad spectrum of activities such as test construction, performance measures, grading, interpreting of standard test scores, communicating results and taking decisions based on the assessment results. They therefore conducted a study into classroom assessment practices and teachers' self-perceived assessment skills. A strong correlation coefficient of 0.71 was found between assessment practices and perceived self-assessment skills such as paper-pencil test, standardised testing, test revision and instructional improvement, performance assessment, and non-achievement based grading.

In a study conducted by Chester and Quitler (as cited in Susuwele-Banda, 2005) to investigate inservice teachers' perception of classroom assessment, standardized testing, and alternative methods, the conclusion drawn was that teacher classroom practices were affected by their perception. They found that teachers who often used standardize test were those that attached less value to classroom assessment. Such teachers were least likely to see the value in assessment for classroom use. Among their recommendations was a focus on in-service training to enable teachers see the value of assessment methods instead of 'how to' assess students for scores. Similarly, Susuwele-Banda (2005) reported the findings of Green's study on pre-service teachers with measurement training. It was found that pre-service teachers claimed standardized test to address important educational outcomes and hence more important than teacher made test or classroom tests. 


\section{Research Methodology}

The study adopted the mixed method design employing both quantitative and qualitative techniques. Particularly, the convergent parallel design was used to collect both quantitative and qualitative data to understand teachers' perception of classroom assessment and their practices in lesson delivery (Creswell \& Plano Clark, 2011). Quantitative technique was used to answer the research questions on teachers' perception and their practices on assessment as well as correlating these two variables of the study. Qualitative technique was also used to seek clarification to issues using open-ended questionnaires (Creswell, 1994; Kuranchie, 2014) and were answered using themes.

The population for the study comprised all senior high school mathematics teachers in the Sunyani West municipality in the Brong Ahafo Region. A sample of 62 mathematics teachers from schools selected in the study area participated in the study. The 62 participants which comprised 52 males and 10 females were selected using simple random sampling technique.

A questionnaire made up of closed-ended and open-ended items was the instrument used to collect data in this study. The closed-ended items sought to collect data on the respondents' perception and practices which were the variables of study. The open-ended items were also used to enable the respondents to freely express their reasons underlying their perception about assessment. To ensure clarity of the items, the questionnaire was pilot tested and the Cronbach alpha reliability coefficient of the closed-ended items was calculated to be 0.74 indicating good internal consistency of the questionnaire items.

The quantitative data collected was analysed using the mean, standard deviation and Pearson product moment correlation coefficient. The qualitative data was also analysed by drawing themes from the responses. The number of responses in the themes of the participants' responses were then determined.

\section{Results and Discussion}

The study sought to investigate senior high school mathematics teachers' perception and practices of classroom assessment. The data collected were analysed in order of the research questions.

Research Question 1: What perception do senior high school mathematics teachers hold about classroom assessment?

The senior high school mathematics teachers' mean rating of statements about reasons for classroom assessments are presented in Table 1. 
Table 1: Senior high school mathematics teachers' mean rating of statements about reasons for classroom assessments

\begin{tabular}{rlll}
\hline S/N & Statements about reasons for classroom assessment & Mean & SD \\
\hline i. & To identify students specific learning difficulties & 3.21 & 0.83 \\
ii. & Assessment motivates students to learn & 3.13 & 0.82 \\
iii. & Means of monitoring students learning & 3.24 & 0.76 \\
iv. & Feedback can be given at anytime & 2.98 & 0.76 \\
v. & Assessment is a means of making decisions about students learning & 3.31 & 0.84 \\
vi. & Assessment is to assign grades & 2.69 & 0.84 \\
vii. & Teaching can be effective with assessment & 3.32 & 0.94 \\
viii. & To determine achievement of learning objectives & 3.24 & 0.88 \\
ix. & Categorizing students for teaching & 3.05 & 0.66 \\
x. & Assessment is meant to promote students & 2.82 & 0.98 \\
xi. & To plan teaching & 3.19 & 0.80 \\
xii. & To determine effectiveness of teaching method & 3.19 & 0.87 \\
xiii. & To give attention to individual students & 3.05 & 0.78 \\
\hline & Mean of Means & 3.11 & 0.69 \\
\hline
\end{tabular}

Table 1 shows that most of the teachers hold positive views about classroom assessment. Interestingly, teachers saw the need for assessment in teaching and learning. It was considered a useful tool to enhance teaching and learning. Thus, the importance of assessment was highly realised by most teachers who participated in the study. Most teachers' responses to assessment were positive as most items had a mean response of 2.5 and above. For instance, teachers believed that it enabled them to identify student learning difficulty and any remedial work if necessary. This confirms the assertion of Ajogbeje (2013) that assessment should be diagnostic in nature as its prime focus is to improve learning by identifying students' learning difficulties and provide remediation if the need be. This enables students to learn from their past mistakes.

Not only is assessment meant to identify learning difficulties but also students' learning strengths. As students thought processes are endorsed by teachers, it gives some sort of self-confidence to students and hence are motivated to learn. This reaffirms the assertion of Oduro (2015) that when assessment is integrated into teaching and learning processes, it can serve as motivation for students' learning. In addition, the respondents saw its importance in their teaching activities. Indeed, it enabled them to plan their teaching, monitor students' learning with the aim of establishing the achievement of learning objectives. This shows that the uses of assessment enable teaching effectiveness to be achieved as indicated by Martinez, Stecher and Barko (2009) and Okyere et al (2018).

On the issue of feedback in assessment, results indicated that most teachers believed that feedback to students could be given at any time. Although most teachers hold positive view about classroom assessment, some of them indicated assessment to be a tool for grading, promoting and perceived 
Senior high school mathematics teachers' perception and use of assessment in the classroom

M. Okyere and E. Larbi

it to be test given to students at the end of course. This corroborates the finding of Susuwele-Banda (2005).

Research Question 2: What factors influence such perceptions about assessment?

Research question two sought to find out what influenced teachers' perception about assessment. In other words, the underlying reason to their perception of classroom assessment. The teachers' responses were analysed into themes (Cohen, Manion \& Morrison, 2005) and the frequencies in these themes were determined. The result is shown in Table 2.

\section{Table 2: Teachers' Reasons for their Perception}

\begin{tabular}{|c|c|c|c|}
\hline $\mathrm{S} / \mathrm{N}$ & Reason & $\begin{array}{l}\text { Number of } \\
\text { teachers }\end{array}$ & Percentage \\
\hline 1 & We test to grade, position and fill students report. & 7 & 11.3 \\
\hline 2 & $\begin{array}{l}\text { Because we want students to know their ability/performance } \\
\text { and that is done only by assessment }\end{array}$ & 3 & 4.8 \\
\hline 3 & Because we assess students when we want to promote them. & 7 & 11.3 \\
\hline \multirow[t]{2}{*}{4} & $\begin{array}{l}\text { Because it's by assessment that we get to know what } \\
\text { students learning progress and what they learnt at the end of } \\
\text { a lesson, topic, term or year. }\end{array}$ & 45 & 72.6 \\
\hline & Total & 62 & 100 \\
\hline
\end{tabular}

Table 2 shows that most (72.6\%) of the mathematics teachers who participated in the study have the reason for their perception about assessment as: 'tool used by teachers to inform teaching and learning processes'. These teachers claimed assessment as a tool that guides teaching and learning activities. Thus, it enables teachers to find out how the students are coping with instruction in relation to the learning targets and also helps the teacher to assess his teaching methods. A typical response of the teachers that falls under this category is

This helps me to know whether the students understand the lesson or not. It also helps me know whether I have to re-teach some aspects of the lesson. It helps me to get a clearer picture of my students learning.

A critical look at the above response signifies the importance of assessment both to the student and the teacher and also in decision making.

The rest of the participants gave their reasons as; assessment as tool for assigning scores or grades to students, tests given to students at the end of topic and promoting students in school. Some of their reasons being that:

Students need to be positioned in class to enable me to know their performance in relation to their friends. It also helps me to fill their terminal reports to enable their parents to see how their wards are performing in the various subjects and their position in class.

Assessment enables me to test my students at the end of every topic or the term to let students know their performance. 
Through assessment or testing, we are able to promote the good ones to the next class/level and to repeat those who are not good. This enables the weak ones improve upon their learning before proceeding to the next class.

The finding of classroom assessment being tests, grading and promotion is also the findings of Susuwele-Banda (2005) who found in a study that teachers perceived assessment as the practice of promoting students from one class to another.

Research Question 3: What kind of assessment practices are utilised by senior high school mathematics teachers in teaching?

This question sought to establish the assessment practices of mathematics teachers in the senior high schools. Responses were analysed using the mean and the standard deviation. The result is presented in Table 3.

Table 3: Teachers' practices of classroom assessment.

\begin{tabular}{rlrc}
\hline S/N & Items & Mean & SD \\
\hline i. & $\begin{array}{l}\text { My marking is based on identifying reasons for which students make } \\
\text { mistakes }\end{array}$ & 2.34 & 0.70 \\
ii. & I frequently assess my students through testing & 3.19 & 0.65 \\
iii. & I provide feedback in terms of scores & 2.87 & 0.86 \\
iv. & I use a scheme for marking all students scripts & 3.27 & 0.81 \\
v. & I often discuss assessment results with students & 2.12 & 0.34 \\
vi. & I use oral questions to identify students difficulties & 2.92 & 0.71 \\
vii. & I ask students to justify answers & 2.42 & 0.88 \\
viii. & I use methods like observation, journal writing, quizzes, etc. to & & \\
& assess my students & 2.06 & 0.72 \\
\hline & Mean of Means & 2.65 & 0.58 \\
\hline
\end{tabular}

Table 3 shows a moderate response on almost all the test items. The results show that teachers frequently assessed their students through the use of tests and provide feedback through scores on performance. Basically, assessment is meant to provide the students with constructive feedback to enable them identify their learning strengths and weaknesses. Just giving students feedback on scores of performances carries very little meaning as far as the purpose of assessment is concerned. It is needful that teachers hold a timely discussion with students based on the performances on the tests given. It is for this reason that formative assessment is often called assessment for learning. The results show that although feedback is given to students on time, there seems to be no further learning from this exercise through discussion. Students should be given the opportunity to learn from their mistakes. Discussing assessment results enable the teachers to get better understanding of student thought processes and to provide a remedy where necessary. The results also, show that teachers do not usually make use of observation, journal writing and projects to assess their 
students. This finding supports the findings of Azuka (2014) that Nigerian mathematics teachers do not make use of oral questions, project and peer groups to assess students' learning difficulties and justification of response to answers given.

Research Question 4: What relationship exists between teachers' perception of classroom assessment and their practices?

To determine the relationship between teachers' perception of classroom assessment and their practices, a correlation analysis was ran and the results are presented in Table 4.

Table 4: Correlation between teachers perception and practices

\begin{tabular}{ll}
\hline Pearson Correlation & 0.171 \\
Significance & 0.184 \\
$\mathrm{~N}$ & 62 \\
\hline
\end{tabular}

The result presented in Table 4 shows that there is a positive but weak correlation coefficient of 0.171 between teachers' perception about classroom assessment and their practices in the classroom. Although the correlation between these two variables is positive, the result at $95 \%$ confidence level is not significant. This shows that upon the positive perception teachers hold about classroom assessment (Table 1), it did not reflect in their classroom practices. In other words, the extent of good knowledge possessed by teachers about assessment is quite different from what is being done in the classroom. This finding however contradicts that of SusuweleBanda (2005) who found in a study that teachers' knowledge about assessment positively influenced their classroom practices. It is quite surprising because it is for the purpose of classroom utilization that teaching and learning of assessment is included in the curriculum of teacher education programmes. This is to ensure that teachers working towards general goal of education would see this important tool as an integral part of executing their duties in the classroom. If students are not constantly assessed during teaching and learning process, then there is doubt in the minds of stakeholders of education as to the kind of efforts made by teachers to determine the learning progress of students as well as the effectiveness of their instruction.

\section{Conclusion}

From the results obtained, it can be concluded that senior high school mathematics teachers who participated in the study hold a positive perception about classroom assessment. The analysis of their reason underlying the use of classroom assessment was found to base on such views that assessment is a tool to improve teaching and learning. There were however some differences in their views where few of them indicated assessment as a means of grading, promoting and giving test to students.

Findings also shows that classroom assessment is fairly practiced in schools, with most of the core purposes of assessment not catered for. This is happening in spite of teachers' adequate knowledge about usefulness of assessment in teaching mathematics.

Also, teachers' classroom practices do not reflect their knowledge possessed about classroom assessment due to positive but weak relationship between the two variables. 


\section{Recommendation}

Based on the findings of the study, it was recommended that;

1. Regular workshops should be organised for teachers on the importance of integrating assessment into teaching and learning of mathematics.

2. Teachers should be encouraged to use various assessment methods in addition to the most often used 'paper and pencil test', and discuss assessment results with students as a means of providing remediation to students' learning difficulties.

3. Teachers should be retrained on the need to integrate assessment practices into teaching and learning as a means to help the realisation of lesson objectives.

\section{References}

Agyei, D. D., \& Mensah, F. S. (2018). Mathematics learning through classroom assessment: Evaluating the value of weekly class tests. African Journal of Educational Studies in Mathematics and Science, 14, 125-138.

Ajogbeje, O. J. (2013). Effects of formative testing on students' achievement in junior secondary school Mathematics. European Scientific Journal, 8(8), 94-105.

Amua-Sekyi, E. T. (2016). Assessment, student learning and classroom practices: A review. Journal of Education and Practice, 7(21), 1-6.

Awoniyi, F. C. \& Fletcher, J. A. (2014). The relationship between senior high school mathematics teacher characteristics and assessment practice. Journal of Education Development and Practice, 4, 21-36.

Azuka, B. F. (2014). Assessment in primary school mathematics classroom in Nigeria. Journal of Education and Practice, 5(30), 40-45.

Cohen, L., Manion, L., \& Morrison, K. (2005). Research methods in education (5 ${ }^{\text {th }}$ ed.). London: Routledge-Falmer.

Creswell, J. W. (1994). Qualitative and quantitative approaches. Thousand Oaks: Sage Publications Ltd.

Creswell, J. W., \& Plano Clark, V. L. (2011). Designing and conducting mixed methods research $\left(2^{\text {nd }}\right.$ ed.). Los Angeles: Sage.

Joshua, M. T. (2005). Fundamentals of tests and measurement in education. Calabar: The University of Calabar Press.

Koloi-Keaikitse, S. (2012). Classroom assessment practices: A survey of Botswana primary and secondary school teachers. A dissertation submitted to Ball State University, Muncie, Indiana [Online] Available at: http://www.cardinalscholar.bus.edu/ (Accessed: 20 July 2016).

Kuranchie, A. (2014). Research made easy. Kumasi: Bookworm Publications.

Martinez, J. F., Stecher, B., \& Barko, H. (2009). Classroom assessment practices, teacher judgements, and students achievement in mathematics: Evidence form the ECLS. Educational Assessment, 14, 78-102. 
Senior high school mathematics teachers' perception and use of assessment in the classroom

M. Okyere and E. Larbi

McMillan, (2008). Assessment essentials for student-based education ( $2^{\text {nd }}$ ed.). Thousand Oaks: Crown Press.

Mussawy, S. A. J. (2009). Assessment practices: Student's and teachers' perceptions of classroom assessment. CIE Master's Capstone Projects. Paper 9. [Online] Available at http://scholarworks.umass.edu/cie_capstones/9 (Accessed: 13 June 2016).

National Council of Teachers of Mathematics (1995). Assessment standards for school mathematics. Reston, VA: Author.

National Council of Teachers of Mathematics (2000). Principles and standards for school mathematics. Reston, VA: Author.

Nitko, A. J. (2001). Educational assessment of students. Englewood Cliffs, NJ: Prentice-Hall, Inc.

Nortvedt, G. A. \& Buchholtz, N. (2018). Assessment in mathematics education: Responding to issues regarding methodology, policy, and equity. $Z D M, 50,555$ - 570. DOI: $10.1007 / \mathrm{s} 11858-018-0963-\mathrm{z}$

Nsikak-Abasi, \& Akanaono, (2017). Impact of classroom assessment, management and control on the academic performance of secondary school students in Akwa Ibom State. Journal of Education and Practice, 8(18), 30 - 36.

Oduro, O. E. (2015). Assessment in mathematics classrooms in Ghana: A study of teachers' practices. [Online] Available at http://sro.sussex.ac.uk (Accessed: 13 June 2016).

Okyere, M., Kuranchie, A., Larbi, E., \& Twene, C. (2018). Essentials of assessment in schools. Sunyani: Aduana Printing Press.

Susuwele-Banda, W. J. (2005). Classroom assessment in Malawi: Teachers' perceptions and practices in mathematics. A dissertation submitted to the Virginia Polytechnic Institute and State University [Online] Available at http://theses.lib.vt.edu (Accessed: 14 May, 2016).

West African Examination Council. (2008). West Africa senior school certificate examination: Chief examiner's report. Accra: Wisdom Press.

West African Examination Council. (2011). West Africa senior school certificate examination: Chief examiner's report. Accra: Wisdom Press.

West African Examination Council. (2014). West Africa senior school certificate examination: Chief examiner's report. Accra: Wisdom Press.

Zhang, Z., \& Burry-Stock, J. A. (2003). Classroom assessment practices and teachers' selfperceived assessment skills. Applied Measurement in Education, 16(4), 323-342. 